\title{
Ichthyofauna of Ranganadi River in Lakhimpur, Assam, India
}

\author{
Gitartha Kaushik* and Sabitry Bordoloi \\ Biodiversity Laboratory, Resource Management and Environment Section, Life Sciences Division, Institute of Advanced Study in \\ Science and Technology, Guwahati, Assam, India 781035 \\ * Corresponding author. E-mail: gitarthakaushik@gmail.com
}

\begin{abstract}
The ichthyofauna of the Ranganadi River, a tributary of the Brahmaputra River in Lakhimpur district, Assam, India, has not been documented so far. To fill this knowledge gap, samples were taken in the Ranganadi River from April 2012 to March 2014, which included 61 species of fishes belonging to six orders, 17 families and 45 genera. One of these species is Endangered, two are as Vulnerable, and six are Near Threatened according to the International Union for the Conservation of Nature. This study will help support the conservation of fish diversity in the Ranganadi River of Assam and the surrounding ecosystems.
\end{abstract}

Key words: fish fauna; Ranganadi River basin; Lakhimpur

\section{INTRODUCTION}

India ranks ninth in terms of freshwater mega biodiversity, with the northeast region recognized as a global hotspot of freshwater fish species (Kottelat and Whitten 1996; Kansal and Arora 2012). Assam, a part of the Indo-Burma biodiversity hotspot, has many torrential streams, which harbour an adapted ichthyofauna (Sen 1999).

Studies on the diversity and conservation of fish in aquatic ecosystems have always attracted the attention of various fishery researchers (Kar et al. 2006). Aquatic ecosystem provides multiple services in terms of supporting aquatic diversity, as well as climate and flood control (Meyer et al. 2007; Tariq et al. 2014). Bagra et al. (2009) surveyed a total of 35 streams and rivers in Arunachal Pradesh including the Subansiri, Ranganadi and upper stretch of the Dikrong and recorded a total of 213 fish species of which 31 species were from Ranganadi in Kimin $\left(27^{\circ} 21^{\prime} 01^{\prime \prime} \mathrm{N}, 093^{\circ} 57^{\prime} 11^{\prime \prime}\right.$ E) and Yazali $\left(27^{\circ} 23^{\prime} 04^{\prime \prime} \mathrm{N}, 093^{\circ} 45^{\prime} 28^{\prime \prime}\right.$ E) area of Papum Pare and Lower Subansiri districts. Sampling of the available ichthyofauna in wetlands of Lakhimpur district was done by Bakalial et al. (2014), who surveyed lower Subansiri River drainage and reported 204 species belonging to 34 families. Hazarika (2013) reported 42 species belonging to 19 families from Satajan wetland of Lakhimpur district.

The present study, geographically confined to the Lakhimpur district, state of Assam, is the first report on documentation of the available ichthyofauna.

\section{MATERIALS AND METHODS \\ Study site}

Lakhimpur district $\left(26^{\circ} 48^{\prime} \mathrm{N}\right.$ to $27^{\circ} 53^{\prime} \mathrm{N}, 093^{\circ} 42^{\prime} \mathrm{E}$ to $094^{\circ} 20^{\prime} \mathrm{E}$ ) encompasses an area of $2,977 \mathrm{~km}^{2}$. The district is bordered by Siang and Papumpare districts of Arunachal Pradesh in the north, Dhemaji district in the east, the Majuli subdivision of Jorhat district in the south, and Gohpur subdivision of Sonitpur district in the west. The four main rivers are the Brahmaputra, Subansiri, Ranganadi and Dikrong.

Ranganadi River $\left(27^{\circ} 11^{\prime} 11^{\prime \prime} \mathrm{N}, 094^{\circ} 03^{\prime} 54^{\prime \prime} \mathrm{E}\right.$ at its entry into the state of Assam), a northern tributary of the Subansiri, originates from Dafla hills of Arunachal Pradesh at an altitude of $3,400 \mathrm{~m}$, flows through the Lesser Himalaya, Outer Himalaya and the valley of the River Brahmaputra (Figure 1). The maximum and minimum discharge of the Ranganadi River ranges between 900 to $130 \mathrm{~m}^{3} / \mathrm{s}$ (unpublished data, Water Resource Department, Lakhimpur District, Government of Assam 2014). The Ranganadi River enters Assam near Johing (27 20'38.96" N, 094 $01^{\prime} 56.23^{\prime \prime}$ E), traverses $60 \mathrm{~km}$ and joins Subansiri

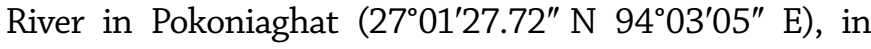
Lakhimpur district of Assam.

\section{Data collection}

Fieldwork was done monthly in the lower stretch of the Ranganadi River $\left(27^{\circ} 18^{\prime} 26.7^{\prime \prime} \mathrm{N}, 094^{\circ} 01^{\prime} 48.1^{\prime \prime}\right.$ E) during April 2012 to March 2014. The fishes were first preserved in $10 \%$ and then transferred to $6 \%$ formaldehyde solution in the laboratory. Morphometric measurements for identification of species were done with vernier calliper (Mitutoyo) to the nearest 0.05 $\mathrm{mm}$ soon after preservation to avoid shrinkage. For molecular analysis, tissue samples were collected and 


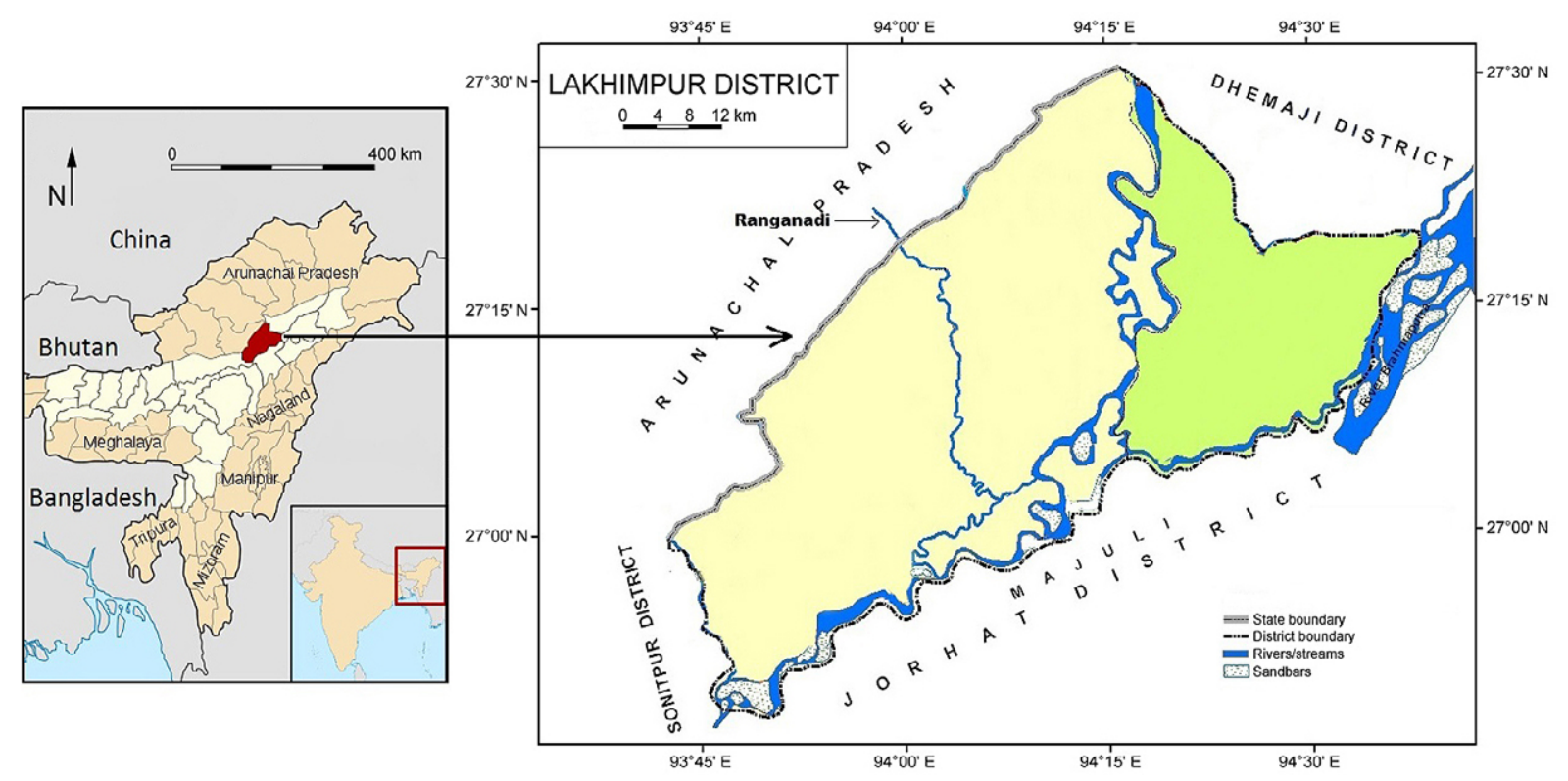

Figure 1. Map of Lakhimpur district showing the Ranganadi River.

preserved in ethanol for some of the voucher specimens before preservation in formaldehyde.

Fishes were identified with the aid of the literature (Jayaram 1999; Nath and Dey 2000; Talwar and Jhingran 1991; Vishwanath et al. 2007). Nomenclature was updated following Froese and Pauly (2015) and Eschmeyer and Fong (2015). The current conservation status of fish species was verified (IUCN 2014). All samples were preserved in the Biodiversity Museum, Institute of Advanced Study in Science and Technology (Guwahati, Assam, India) and given voucher numbers (IASST F 120 to IASST F 180; Appendix, Table A1).

\section{RESULTS}

In the present study, 61 species, belonging to six orders, 19 families and 44 genera were recorded (Figure 2). One species is assessed as Endangered, six species are Near Threatened, two species are Vulnerable, and the other 46 species are Least Concern according the International Union for the Conservation of Nature (IUCN 2014). One additional species is Not Evaluated and four species are Data Deficient (IUCN 2014).

Cyprinidae is the most species rich family, with 20 species belonging to 16 genera. Next in species richness are Sisoridae with 6 spp., 3 genera), Cobitidae (5 spp., 3 genera), Bagridae (4 spp., 3 genera), Nemacheilidae (3 spp., 3 genera), Erethistidae (3 spp., 2 genera), Badidae and Psilorhynchidae (each with 3 spp., 1 genus), Ambassidae (2 spp., 2 genera), Amblycipitidae and Olyridae (each with 2 spp., 1 genus), Balitoridae, Schilbeidae, Siluridae, Gobiidae, Channidae, Anguillidae, Mastacembelidae, Belonidae (each with 1 sp.).

Altogether, $32.8 \%$ of the fish species recorded belong to the family Cyprinidae, $9.8 \%$ to Sisoridae, $8.2 \%$ to Cobitidae, $6.6 \%$ to Bagridae, $4.9 \%$ to Erethistidae, Badidae, Psilorhynchidae and Nemacheilidae, 3.3\% to Olyridae, Ambassidae and Amblycipitidae, $1.6 \%$ to Balitoridae, Gobiidae, Mastacembelidae, Channidae, Belonidae, Anguillidae, Schilbeidae and Siluridae. Endangered fish (Amblyceps arunachalensis), Vulnerable fishes (Devario assamensis and Botia rostrata), and Near Threatened fishes (Balitora brucei, Tor tor, Aborichthys kempi, Glyptothorax striatus and Anguilla bengalensis) were also recorded during the survey. Eleven of the 61 recorded species are coldwater fishes, seven species are warm-cold water fishes, 21 species are warmwater fishes and the other 21 species were not categorised as per Kapoor et al. (2002).

Ojha and Singh (1992) characterized the fish species from hill streams as inhabitants of swift, turbulent and cascading hyperoxic water, and these species exhibit a number of adaptive modifications. The ichthyofauna is composed of 27 "hill stream species" and 29 riverine species (Froese and Pauly 2015; Ojha and Singh 1992). Our study also recorded five migratory species (Froese and Pauly 2015) (Table 1).

Species such as Badis badis, Barilius bendelisis, Acanthocobitis botia, Chanda nama were more abundant (B.bendelisis $=110 / 400$, B.badis $=68 / 400$, A. botia $=$ 57/400, C. nama $=42 / 400$ ). However, only one specimen for Tor tor, Anguilla bengalensis, Devario assamensis and Mastacembelus armatus were captured. Badis badis and Chanda nama could be collected only in post-monsoon season and at the beginning of the winter.

\section{DISCUSSION}

Anthropogenic activities such as the construction of dams for a hydroelectric power project in the upper or middle stretches of rivers may influence hydrology of dammed rivers as well as the efficiency of the channel downstream of the dam site (Dynesius and Nilsson 1994; Baxter 1997; Batalla et al. 2004). Downstream, 
Table 1. List of fishes from the Ranganadi River. $E N=$ Endangered, $V U=$ Vulnerable, $N E=$ Not Evaluated, $D D=$ Data Deficient, $L C=$ Least Concern, $\mathrm{NT}=$ Near Threatened, $\mathrm{H}=$ Hill Stream, $\mathrm{R}=$ Riverine and $\mathrm{MF}=$ Migratory Fish.

\begin{tabular}{|c|c|c|c|c|c|}
\hline \multirow{2}{*}{ Order } & \multirow[b]{2}{*}{ Species } & \multirow[b]{2}{*}{ IUCN Red List status } & \multicolumn{3}{|c|}{ Habitat } \\
\hline & & & H & $\mathbf{R}$ & M.F \\
\hline \multirow[t]{20}{*}{ Cypriniformes } & Barilius bendelisis (Hamilton, 1807) & $\mathrm{LC}$ & - & - & + \\
\hline & Barilius vagra (Hamilton, 1822) & $\mathrm{LC}$ & + & - & - \\
\hline & Barilius shacra (Hamilton, 1822) & LC & - & + & - \\
\hline & Danio dangila (Hamilton, 1822) & LC & + & - & - \\
\hline & Cabdio morar (Hamilton, 1822) & LC & - & + & - \\
\hline & Garra gotyla (Gray, 1830) & LC & + & - & - \\
\hline & Psilorhynchus balitora (Hamilton, 1822) & LC & + & - & - \\
\hline & Acanthocobitis botia (Hamilton, 1822) & LC & - & + & - \\
\hline & Aborichthys kempi Chaudhuri, 1913 & NT & + & - & - \\
\hline & Puntius guganio (Hamilton, 1822) & LC & - & + & - \\
\hline & Pethia ticto (Hamilton, 1822) & LC & - & + & - \\
\hline & Aspidoparia jaya (Hamilton, 1822)* & LC & - & + & - \\
\hline & Danio rerio (Hamilton, 1822) & LC & - & + & - \\
\hline & Labeo dyocheilus (McClelland, 1839) & LC & - & - & + \\
\hline & Garra annandalei Hora, 1921 & $\mathrm{LC}$ & + & - & - \\
\hline & Tor tor (Hamilton, 1822) & NT & - & - & + \\
\hline & Canthophrys gongota (Hamilton, 1822) & LC & - & + & - \\
\hline & Botia almorhae Gray, 1831 & $\mathrm{LC}$ & + & - & - \\
\hline & B. rostrata Günther, 1868 & Vu & + & - & - \\
\hline & Psilorhynchus arunachalensis (Hamilton, 1822) & $\mathrm{DD}$ & + & - & - \\
\hline \multirow[t]{19}{*}{ Siluriformes } & Amblyceps sp. & - & + & - & - \\
\hline & Amblyceps arunchalensis Nath \& Dey, 1889 & EN & + & - & - \\
\hline & Olyra kempi Chaudhuri, $1912^{* *}$ & LC & + & - & - \\
\hline & Mystus dibrugarensis (Chaudhuri 1913) & LC & - & + & - \\
\hline & Eutropiichthys vacha (Hamilton, 1822) & LC & - & - & + \\
\hline & Gagata cenia (Hamilton, 1822) & LC & - & + & - \\
\hline & Batasio tengana (Hamilton, 1822) & LC & - & + & - \\
\hline & Mystus vittatus (Bloch, 1794) & LC & - & + & - \\
\hline & Erethistoides montana Hora, 1950 & DD & + & - & - \\
\hline & Olyra longicaudata McClelland, 1842 & LC & + & - & - \\
\hline & Wallago attu (Bloch \& Schneider, 1801) & NT & - & + & - \\
\hline & Sperata seenghala ( Skyes,1939) & $\mathrm{LC}$ & - & + & - \\
\hline & Glyptothorax cavia (Hamilton, 1822) & LC & + & - & - \\
\hline & G. striatus (McClelland, 1842) & NT & + & - & - \\
\hline & Pseudolaguvia ferula Ng, 2006 & $\mathrm{DD}$ & + & - & - \\
\hline & Pseudolaguvia shawi(Hora, 1921) & LC & + & - & - \\
\hline & Nangra assamensis Sen \& Biswas, 1994 & LC & - & + & - \\
\hline & Glyptothorax telchitta (Hamilton,1822) & $\mathrm{LC}$ & + & - & - \\
\hline & Glyptothorax trilineatus Blyth, 1860 & LC & + & - & - \\
\hline
\end{tabular}

* In Eschmeyer and Fong (2015), Aspidoparia jaya is mentioned as Cabdio jaya.

** Olyra kempi is mentioned as the synonym for Olyra longicaudata. 

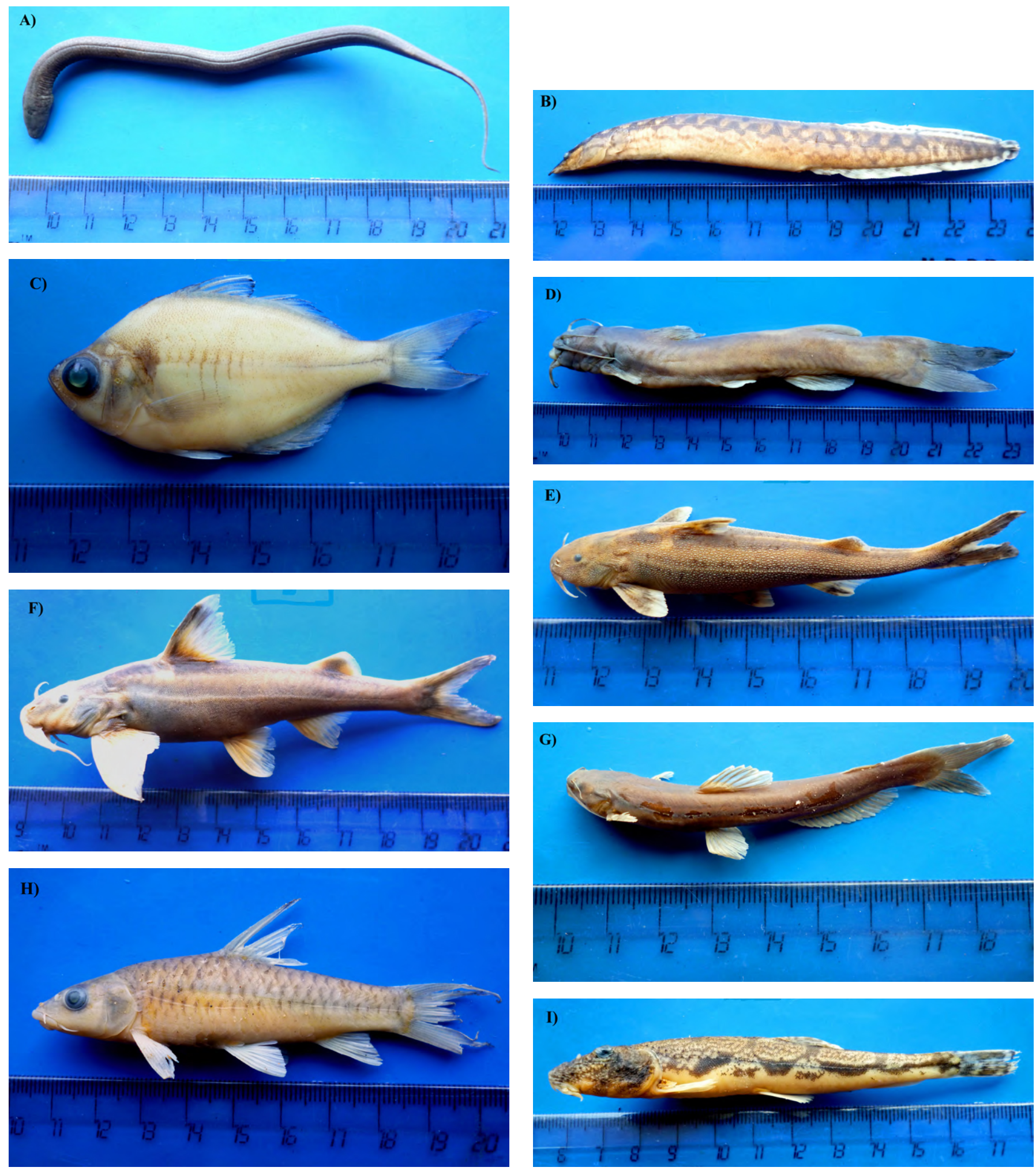

Figure 2. Indigenous fishes collected from April 2012 to March 2014 in the Ranganadi River. A: Anguilla bengalensis. B: Mastacembelus armatus. C: Parambassis baculis. D: Amblyceps arunchalensis. E: Glyptothorax telchiita. F: Glyptothorax trilineatus. G: Olyra kempi. H: Tor tor. I: Canthophrys gongota.

the Ranganadi River experiences the effects of having the North Eastern Electric Power Corporation (NEEPCO) dam, with a capacity of $405 \mathrm{MW}\left(27^{\circ} 20^{\prime} 03^{\prime \prime}\right.$ N, 093 $49^{\prime} 00^{\prime \prime}$ E) at Yazali in Lower Subansiri district, Arunachal Pradesh. The modified river flow downstream of the dam have a variety of negative effects on the fish fauna, including loss of stimuli for migration, loss of routes for migration and spawning grounds, decrease in the survival of eggs and juveniles, and diminished food production (Kansal and Arora 2012). Besides these known impacts, the presence of high species diversity reduces disease problems and encourages recovery from disturbances (Kar et al. 2006). The NEEPCO dam might have affected the fishes and eventually the diversity 
of the fishes in the lower stretch the Ranganadi River. However, 61 fish species were recorded in the Ranganadi River within Assam, including a number of threatened species.

The Ranganadi River enters Assam on a steep gradient and gradually becomes a slow flowing river before joining the Subansiri River at Pokoniaghat. Presence of $A$. arunchalensis, A. bengalensis, A. kempi, B. brucei, $B$. rostrata, D. assamensis, G. striatus, T. tor and Wallago attu shows the presence of many different microhabitats within the river, which are important for feeding and breeding. These features could also help increase the ichthyofaunal diversity in the Ranganadi River.

Fishes such as Tor tor, Labeo dyocheilus, Barilius bendelisis, Anguilla bengalensis and Glossogobius giuris can migrate long distances in trans-Himalayan rivers (Talwar and Jhingran, 1991; Das and Bordoloi 1997; Hill and Hill 1994; Menon 1999). Depending on the water quality and environmental factors such as temperature and rainfall, these fish species migrate to the large rivers for feeding or breeding.

Fish ladders are generally believed to re-establish connectivity between critical habitats for migratory species and reduce the anthropogenic stress on the fish fauna. However, to be useful, fish ladders must assure both upward and downward movements of fishes. It is imperative to maintain a minimum water flow, especially during the winter, when the contribution of the rainfall greatly decreases (Agostinho et al. 2007).

\section{ACKNOWLEDGEMENTS}

This study was supported by research grants from the Institute of Advanced Study in Science and Technology (Guwahati, Assam, India). The authors express their gratitude to Dr. Mrinal Kumar Das, Jafrin Farha Hussain, and Manas Das for their valuable help during the preparation of the manuscript. We are also thankful to the volunteers from the Johing Tea Garden for their kind assistance during the fieldwork.

\section{LITERATURE CITED}

Agostinho, A.A., E.E. Marques, C.S. Agostinho, D.A. de Almeida, R.J. Oliveira, and J.R.B. de Melo. 2007. Fish ladder of Lajeado dam: Migrations on one way routes? Neotropical Ichthyology 5(2): 121-130. doi: 10.1590/S1679-62252007000200005

Bagra, K., K. Kadu, K. Nebeswahwar, B.A. Laskar, U.K. Sarkar and D.N. Das. 2009. Ichthyological survey and review of the checklist of fish fauna of Arunachal Pradesh, India. Check List 5(2): 330-350. http://www.checklist.org.br/getpdf?SL111-08

Bakalial, B., S.P. Biswas, S. Borah and D. Baruah. 2014. Checklist of fishes of Lower Subansiri River drainage, northeast India. Annals of Biological Research 5(2): 55-67. http://scholarsresearchlibrary. com/ABR-vol5-iss2/ABR-2014-5-2-55-67.pdf

Batalla, R.J., C.M. Gomez and G.M. Kondolf. 2004. Reservoirinduced hydrological changes in the Ebro River basin (NE Spain). Journal of Hydrology 290: 117-136.

Baxter, R.M. 1997. Environmental effects of dams and impoundments. Annual Review of Ecology and Systematics 8: 255-283. doi: $10.2307 / 2096729$

Daimari, P., M. Choudhury and A. Dutta. 2005. Ecology and Fishery of River Subansiri (Arunachal Pradesh). Environment and Ecology 23(1): 49-54.

Das, P. and S.C. Bordoloi. 1997. Fish fauna of a torrential River (Basistha) in Kamrup district Assam, India. Journal of Inland Fisheries Society of India 29(1): 54-58.

Dynesius, M. and C. Nilsson. 1994. Fragmentation and flow regulation of river systems in the northern third of the world. Science 266(5186): 753-762. doi: 10.1126/science.266.5186.753

Eschmeyer, W.N. and J.D. Fong. 2015. Catalog of fishes: genera, species, references. San Francisco: California Academy of Sciences. Accessed at http://researcharchive.calacademy.org/research/ ichthyology/catalog/SpeciesByFamily.asp on 5 March 2015.

Froese, R. and D. Pauly. 2014. FishBase. Version 02/2014. World Wide Web electronic publication. Accessed at http://fishbase. org/search.php, 30 March 2014.

Hazarika, L.P. 2013. Astudy of certain physico-chemicalcharacteristics of Satajan wetland with special reference to fish diversity indices, Assam, India. European Journal of Experimental Biology 3(4): 173-180. http://pelagiaresearchlibrary.com/european-journalof-experimental-biology/vol3-iss4/EJEB-2013-3-4-173-180.pdf

Hill, M.T. and S.A. Hill. 1994. Fisheries ecology and hydropower in the lower Mekong River: an evaluation of run-of-the river projects. Bangkok: Mekong Secretariat. $106 \mathrm{pp}$.

IUCN. 2014. The IUCN Red list of threatened species. Version 2014.1.International Union for Conservation of Nature. Accessed at http://www.iucnredlist.org, 30 March 2014.

Jayaram, K.C. 1999. The freshwater fishes of the Indian region. New Delhi: Narendra Publishing House. 551 pp.

Kapoor, D., R. Dayal and A.G. Ponniah. 2002. Fish biodiversity of India. Lucknow: National Bureau of Fish Genetic Resources. 775 pp.

Kar, D., A.V. Nagarathna, T.V. Ramachandra and S.C. Dey. 2006. Fish diversity and conservation aspect in an aquatic ecosystem in northeastern India. Zoos' Print Journal 21(7): 2308-2315. http://www.zoosprint.org/ZooPrintJournal/2006/July/23082315.pdf

Kansal, M.L. and S. Arora. 2012. Biodiversity and present status of freshwater fishes in Lohit River basin of India. Environmentalist 32: 58-69. doi: 10.1007/s10669-011-9372-3.

Kottelat, M. and T. Whitten .1996. Freshwater biodiversity in Asia with special reference to fish: World Bank Technical Paper No. 343. Washington: The World Bank. 59 pp.

Menon, A.G.K. 1999. Check list - fresh water fishes of India. Records of Zoological Survey of India, Miscellaneous Publication, Occasional Paper 175: 1-366.

Nath, P. and S.C. Dey. 2000. Fish and fisheries of north eastern India (Arunachal Pradesh). New Delhi: Narendra Publishing House. $217 \mathrm{pp}$.

Ojha, J. and S.K. Singh. 1992. Functional morphology of the anchorage system and food scrapers of a hill stream fish, Garra lamta (Ham.). Journal of Fish Biology 41: 159-161. doi: 10.1111/j.10958649.1992.tb03181.x

Sen, N. 1998. On a collection of fishes from Subansiri and Siang districts of Arunachal Pradesh, India. Records of Zoological Survey of India 97(1): 141-144.

Talwar, P.K. and A.G. Jhingran. 1991. Inland fishes of the India and adjacent countries. Volume 1: 1-541. New Delhi: Oxford and IBH Publishing Co.

Talwar, P.K. and A.G. Jhingran. 1991. Inland fishes of the India and adjacent countries. Volume 2: 543-1158. New Delhi: Oxford and IBH Publishing Co.

Tamang, L., S. Chaudhry, and D. Choudhury. 2007. Ichthyofaunal Contribution to the state and comparison of habitat contiguity on taxonomic diversity in Senkhi stream, Arunachal Pradesh, India. Journal of the Bombay Natural History Society 104(2): 
172-179.

Tariq, M.A.U.R., O.A.C. Hoes and N.C. Van de Giessen. 2014. Development of a risk-based framework to integrate flood insurance. Journal of Flood risk management 7(4): 291-307. doi: 10.1111/ jfr3.12056

Vishwanath, W., W.S. Lakra and U.K. Sarkar. 2007. Fishes of northeast India. Lucknow: National Bureau of Fish Genetic Resources. 264 pp.
Author contributions: GK made the collections, data analysis and prepared the manuscript. SB is the Ph.D supervisor.

Received: 2 January 2015

Accepted: 17 March 2016

Academic editor: Marina Loeb

\section{APPENDIX}

Table A1. Voucher numbers of the samples deposited in the museum of Institute of Advanced Study in Science and Technology (IASST).

\begin{tabular}{|c|c|c|c|c|c|}
\hline Species & Voucher No. & Species & Voucher No. & Species & Voucher No. \\
\hline Barilius bendelisis & IASST F 120 & Canthophrys gongota & IASST F 141 & Pseudolaguvia ferula & IASST F 162 \\
\hline B. vagra & IASST F 121 & Botia almorhae & IASST F 142 & P. seudolaguvia shawi & IASST F 163 \\
\hline B. shacra & IASST F 122 & Botia rostrata & IASST F 143 & Nangra assamensis & IASST F 164 \\
\hline Danio dangila & IASST F 123 & B. histrionica & IASST F 144 & Glyptothorax telchitta & IASST F 165 \\
\hline Cabdio morar & IASST F 124 & Osteobrama cotio cotio & IASST F 145 & G. trilineatus & IASST F 166 \\
\hline Lepidocephalichthys guntea & IASST F 125 & Devario assamensis & IASST F 146 & Parambassis baculis & IASST F 167 \\
\hline Garra gotyla gotyla & IASST F 127 & Laubuka laubuca & IASST F 148 & Badis badis & IASST F 169 \\
\hline Psilorhynchus balitora & IASST F 128 & Cirrhinus reba & IASST F 149 & Badis singenensis & IASST F 170 \\
\hline Acanthocobitis botia & IASST F 129 & Amblyceps sp. & IASST F 150 & Badis kanabos & IASST F 171 \\
\hline Aborichthys kempi & IASST F 130 & Amblyceps arunachalensis & IASST F 151 & Glossogobius giuris & IASST F 172 \\
\hline Schistura tirapensis & IASST F 131 & Olyra kempi & IASST F 152 & Channagachua & IASST F 173 \\
\hline Balitora brucei & IASST F 132 & Mystus dibrugarensis & IASST F 153 & Anguilla bengalensis & IASST F 174 \\
\hline Crossocheilus latius & IASST F 133 & Gagata cenia & IASST F 154 & Mastacembelus armatus & IASST F 175 \\
\hline Pethia ticto & IASST F 135 & Mystus vittatus & IASST F 156 & Psilorhynchus arunachalensis & IASST F 177 \\
\hline Aspidoparia jaya & IASST F 136 & Erethistoides montana & IASST F 157 & Glyptothorax striatus & IASST F 178 \\
\hline Danio rerio & IASST F 137 & Olyra longicaudata & IASST F 158 & Eutropiichthys vacha & IASST F 179 \\
\hline Labeo dyocheilus & IASST F 138 & Wallago attu & IASST F 159 & Rasbora daniconius & IASST F 180 \\
\hline Garra annandalei & IASST F 139 & Sperata seenghala & IASST F 160 & & \\
\hline Tortor & IASST F 140 & Glyptothorax cavia & IASST F 161 & & \\
\hline
\end{tabular}

